\title{
The travel-related carbon dioxide emissions of atmospheric researchers
}

\author{
A. Stohl \\ Norwegian Institute for Air Research, Kjeller, Norway \\ Received: 26 March 2008 - Published in Atmos. Chem. Phys. Discuss.: 16 April 2008 \\ Revised: 22 September 2008 - Accepted: 5 October 2008 - Published: 13 November 2008
}

\begin{abstract}
Most atmospheric scientists agree that greenhouse gas emissions have already caused significant changes to the global climate system and that these changes will accelerate in the near future. At the same time, atmospheric scientists who - like other scientists - rely on international collaboration and information exchange travel a lot and, thereby, cause substantial emissions of $\mathrm{CO}_{2}$. In this paper, the $\mathrm{CO}_{2}$ emissions of the employees working at an atmospheric research institute (the Norwegian Institute for Air Research, NILU) caused by all types of business travel (conference visits, workshops, field campaigns, instrument maintainance, etc.) were calculated for the years 2005-2007. It is estimated that more than $90 \%$ of the emissions were caused by air travel, $3 \%$ by ground travel and $5 \%$ by hotel usage. The travelrelated annual emissions were between 1.9 and $2.4 \mathrm{tCO}_{2}$ per employee or between 3.9 and $5.5 \mathrm{tCO}_{2}$ per scientist. For comparison, the total annual per capita $\mathrm{CO}_{2}$ emissions are $4.5 \mathrm{t}$ worldwide, $1.2 \mathrm{t}$ for India, $3.8 \mathrm{t}$ for China, $5.9 \mathrm{t}$ for Sweden and $19.1 \mathrm{t}$ for Norway. The travel-related $\mathrm{CO}_{2}$ emissions of a NILU scientist, occurring in 24 days of a year on average, exceed the global average annual per capita emission. Norway's per-capita $\mathrm{CO}_{2}$ emissions are among the highest in the world, mostly because of the emissions from the oil industry. If the emissions per NILU scientist derived in this paper are taken as representative for the average Norwegian researcher, travel by Norwegian scientists would nevertheless account for a substantial $0.2 \%$ of Norway's total $\mathrm{CO}_{2}$ emissions. Since most of the travel-related emissions are due to air travel, water vapor emissions, ozone production and contrail formation further increase the relative importance of NILU's travel in terms of radiative forcing.
\end{abstract}

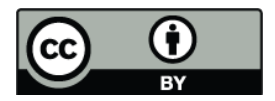

Correspondence to: A. Stohl (ast@nilu.no)

\section{Introduction}

The global atmospheric concentration of carbon dioxide $\left(\mathrm{CO}_{2}\right)$ has increased from a pre-industrial value of about $280 \mathrm{ppm}$ to $379 \mathrm{ppm}$ in 2005 (IPCC, 2007). The primary source of this increased atmospheric concentration results from fossil fuel use, with land-use change providing another significant but smaller contribution. The enhanced atmospheric $\mathrm{CO}_{2}$ concentrations produced a radiative forcing of $1.66 \mathrm{~W} \mathrm{~m}^{-2}$ in the year 2005 (IPCC, 2007), which is the largest contribution of all forcing agents to the total radiative forcing. The transport sector is one of the largest sources, contributing about $19 \%$ of all $\mathrm{CO}_{2}$ emissions according to the EDGAR 3.2 fast track inventory for the year 2000 (Olivier et al., 2001). Emissions of $\mathrm{CO}_{2}$ by aircraft were $0.51 \mathrm{GtCO}_{2} /$ year in 1992 , about $2 \%$ of total anthropogenic carbon dioxide emissions or about $13 \%$ of carbon dioxide emissions from all transportation sources (Penner et al., 1999). Aircraft emissions have been growing at a fast rate and in the year 2005 have reached about $0.65 \mathrm{GtCO}_{2} /$ year (Kim et al., 2007). Technological improvements will not be able to compensate for the increasing demand on air travel, such that a continued growth of $\mathrm{CO}_{2}$ emissions is expected for the next few decades (Lee et al., 2001).

Most atmospheric scientists are concerned that greenhouse gas emissions have already caused significant changes to the global climate system and that these changes will accelerate in the near future. At the same time, atmospheric scientists - as all other scientists - rely on the international exchange of information and on international collaboration. Often, this requires traveling to conferences, workshops or project meetings. Atmospheric researchers also perform field campaigns or maintain monitoring sites in sometimes remote locations. The $\mathrm{CO}_{2}$ emissions from the resulting travel, if counted on a per-capita basis, are likely to be substantial. Estimates for the $\mathrm{CO}_{2}$ emissions caused by the travel to individual scientific conferences have been made. For instance,

Published by Copernicus Publications on behalf of the European Geosciences Union. 
Table 1. Number of persons employed at NILU in total and for scientists only in the years 2005, 2006 and 2007. For 2005, employees working in the Troms $\varnothing$ office are not counted because of incomplete travel information.

\begin{tabular}{rrr}
\hline Year & Personnel & Scientists \\
\hline 2005 & 134 & 60 \\
2006 & 152 & 73 \\
2007 & 160 & 79 \\
\hline
\end{tabular}

Krause et al. (2007) evaluated the carbon footprint of different travel options to the European Geosciences Union General Assembly. Recently, the International Global Atmospheric Chemistry project made efforts to accurately quantify the $\mathrm{CO}_{2}$ footprint of their tenth International Conference, with the aim to compensate for the $\mathrm{CO}_{2}$ emissions caused by the conference (see http://www.igacfrance2008. fr/index.php?page=carbon-neutral-conference). However, to my knowledge a comprehensive quantification of the overall travel-related $\mathrm{CO}_{2}$ emissions by scientists has not yet been published in the open literature.

In this paper, I make a first case study by estimating the $\mathrm{CO}_{2}$ emissions caused by all business trips undertaken by the employees of my institute, the Norwegian Institute for Air Research (NILU), during the years 2005-2007. NILU's staff has grown from 134 to 160 persons during this period, 60 to 79 of whom were scientists (Table 1). Most of NILU's employees are working in Kjeller (about $20 \mathrm{~km}$ outside Oslo) but NILU also has a small office in Troms $\emptyset$ with a staff of about 12 consisting mainly of scientists. I am quantifying the $\mathrm{CO}_{2}$ emissions caused by air travel, ground transportation and hotel use. I am ignoring all other emissions (e.g., related to food consumption, purchase of goods, use of conference facilities and materials, etc.), assuming that they are either negligible or would have occurred also at home. Furthermore, only emissions caused directly by business trips are calculated; emissions from the daily commute to work, the operation of the institute (e.g., building heating), or occurring in the scientists' private life, are not accounted for. Finally, I am comparing the business-travel-related $\mathrm{CO}_{2}$ emissions to the total emissions from various countries on a per-capita basis.

\section{Methods}

The basis for this study are files available from NILU's administration department listing all trips undertaken by NILU's staff during the years 2005-2007. The files contain the travelers' names, the reasons for a trip, its duration and destination. The destinations' geographical coordinates, if unavailable, were determined by searching for city and other location names in the Wikipedia on-line encyclopedia (see
http://en.wikipedia.org/wiki/Main_Page). Most of the coordinates are not those of an airport but of the traveller's final destination. Figure 1 shows all destinations and great circle routes from the home airport, and Table 2 lists the number of trips undertaken every year (381-557). It is seen that while European destinations generally dominate, a substantial number of trips were made to destinations outside $\mathrm{Eu}-$ rope. Travel within Norway, except for travel between the offices in Kjeller and Troms $\varnothing$ (also an almost 2-h-long flight), is relatively unimportant. Trips in the institute's immediate vicinities were ignored completely while for the remaining trips within Norway it was assumed that air travel was used. Errors resulting from these assumptions would impact the annual $\mathrm{CO}_{2}$ budget by less than $1 \%$.

From the available information, the total flight distance covered by a trip is calculated to be

$D=2 F_{1} F_{2} D_{G C}$

where $D_{G C}$ is the great-circle distance between the Oslo (or Troms $\varnothing$ ) airport and the destination location. The factor 2 accounts for the return trip, $F_{1}=1.1$ corrects for the average deviation of actual flight lengths from great circle distance (about $10 \%$, according to Kim et al., 2007), and $F_{2}$ is an empirical correction factor. The factor $F_{2}$ is applied here because only the final destination of a trip is known but the actual routing may have involved more than one flight which increases the total distance traveled and also reduces the fuel use efficiency as shorter flights have a lower efficiency (see below). We take $F_{2}$ to be 1.0 and 1.2 for $D_{G C}$ less than $800 \mathrm{~km}$ and more than $800 \mathrm{~km}$, respectively, assuming that short distances are always covered by direct flights while long distances often require two or more flights.

The $\mathrm{CO}_{2}$ emission per flight kilometer is calculated according to

$E=\frac{C E_{U}}{H L}$

where $C$ is the emission factor for $\mathrm{CO}_{2}, 3.15 \mathrm{~kg} \mathrm{CO}_{2} / \mathrm{kg}$ jet fuel; $E_{U}$ is the specific energy usage per available seat kilometer (ASK), taken to be 1.2 MJ/ASK and 2.0 MJ/ASK for flights of more than $1000 \mathrm{~km}$ and less than $1000 \mathrm{~km}$, respectively (Babikian et al., 2002). The higher fuel consumption for the shorter flights is due to the larger fraction of time spent taxiing at airports and in the fuel-intensive ascent phase; $H$ is the lower heating value of kerosine, $43.1 \mathrm{MJ} / \mathrm{kg}$; $L$ is the average passenger load factor, assumed to be 0.75 (Morrell, 2007).

Combining Eqs. (1) and (2), the $\mathrm{CO}_{2}$ emissions of a trip can be calculated, which are then summed over all trips of a year. Overall, I estimate that annual $\mathrm{CO}_{2}$ emissions calculated with the above procedure are accurate to within about $30 \%$. The largest uncertainties are due to $E_{U}$ varying by about $20-30 \%$ between different aircraft types and depending on flight length (Babikian et al., 2002), the empirical factor $F_{2}$, and the passenger load factor, which can be quite 
Table 2. Number of business trips undertaken by NILU personnel, total distance traveled (million $\mathrm{km}$ ), and distance traveled per employee $(1000 \mathrm{~km})$ and per scientist $(1000 \mathrm{~km})$, as well as related $\mathrm{CO}_{2}$ emissions from transportation by NILU personnel in total $\left(\mathrm{tCO}_{2}\right)$, per employee $\left(\mathrm{tCO}_{2}\right)$ and per scientist $\left(\mathrm{tCO}_{2}\right)$ for the years 2005, 2006 and 2007. Trips from Troms $\varnothing$ were accounted for only in 2006 and 2007.

\begin{tabular}{lrrrrrrr}
\hline Year & Trips & $\begin{array}{r}\text { Travel distance } \\
{[\text { million km }]}\end{array}$ & $\begin{array}{r}\text { Distance per employee } \\
{[1000 \mathrm{~km}]}\end{array}$ & $\begin{array}{r}\text { Distance per scientist } \\
{[1000 \mathrm{~km}]}\end{array}$ & $\begin{array}{r}\mathrm{CO}_{2} \\
{\left[\mathrm{tCO}_{2}\right]}\end{array}$ & $\begin{array}{r}\mathrm{CO}_{2} \text { per employee } \\
{\left[\mathrm{tCO}_{2}\right]}\end{array}$ & $\begin{array}{r}\mathrm{CO}_{2} \text { per scientist } \\
{\left[\mathrm{tCO}_{2}\right]}\end{array}$ \\
\hline 2005 & 403 & 2.6 & 19.4 & 43.2 & 311 & 2.3 & 5.2 \\
2006 & 381 & 2.2 & 14.6 & 30.5 & 269 & 1.8 & 3.7 \\
2007 & 557 & 3.0 & 18.8 & 38.2 & 368 & 2.3 & 4.7 \\
\hline
\end{tabular}

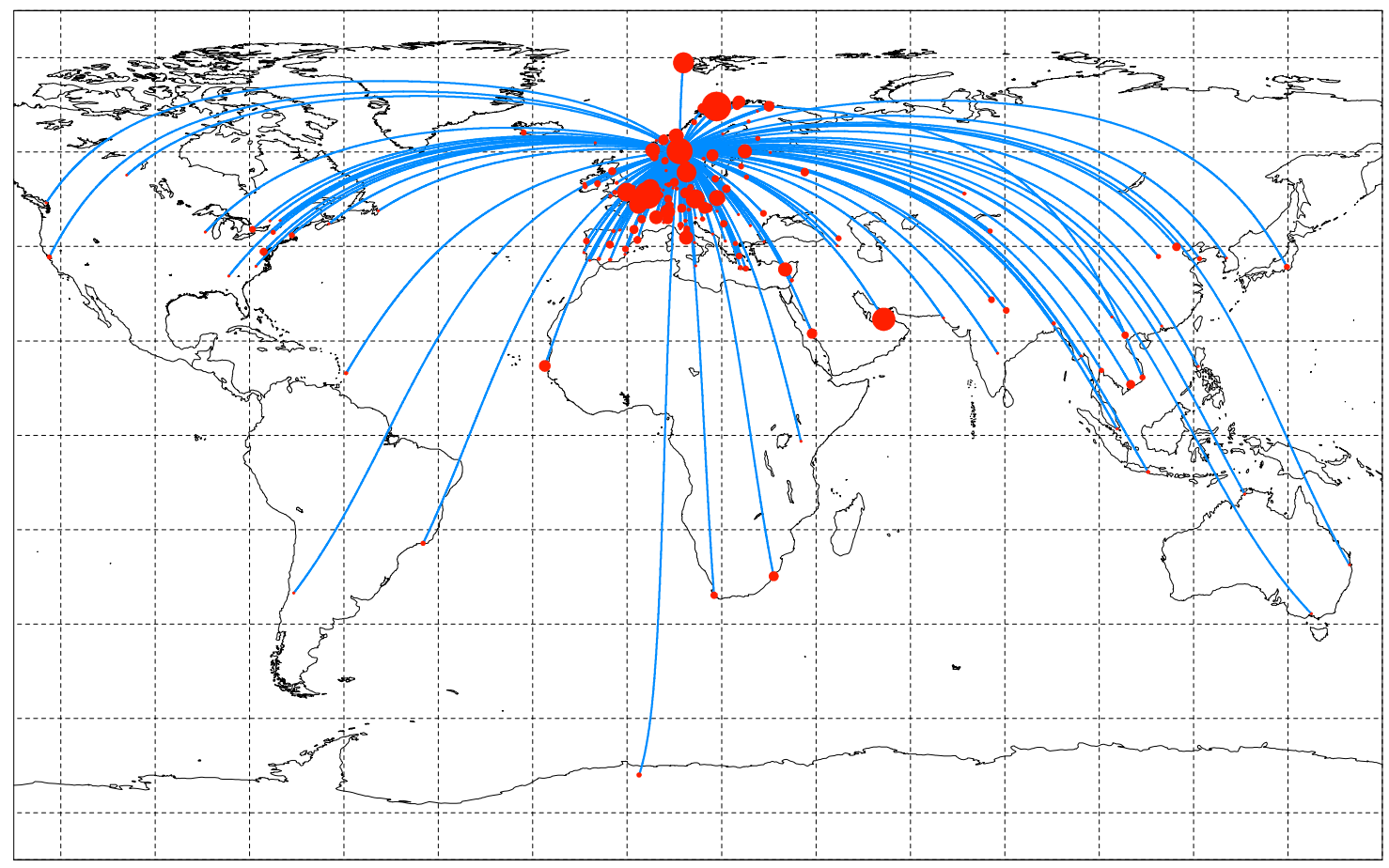

Fig. 1. Summary of all trips undertaken by NILU staff during 2005-2007. The blue lines are great circle routes from the home airport to the destination; the red circles mark the destination locations, with the circles' area being proportional to the number of trips undertaken.

different for different airlines. Morrell (2007) give $L$ values between 0.51 and 0.91 for different airlines (the higher values are for a charter company and are not representative for the business travel considered here). The various parameters in Eq. (1) and (2) were chosen such that the $\mathrm{CO}_{2}$ emission estimates are thought to be conservative - thus, underestimation is more likely than overestimation.

For every trip undertaken by a NILU employee, I have added $160 \mathrm{~km}$ of ground travel, assuming that about $80 \mathrm{~km}$ are required for the return trip between employees' homes and the airport (Gardermoen airport is about $50 \mathrm{~km}$ outside Oslo), $60 \mathrm{~km}$ are required for the return trip between the destination airport and the final destination (assuming this to be a typical distance of an airport from a city center), and $20 \mathrm{~km}$ are covered at the destination site. These numbers are thought to be very conservative. I have assumed that $0.03 \mathrm{~kg} / \mathrm{km}$ gasoline are consumed for ground transportation on average, again a conservative estimate given that taxis or private cars are often used. In total, ground transportation contributed less than $3 \%$ to total emissions, such that a more refined procedure was not deemed necessary.

$\mathrm{CO}_{2}$ emissions occur also during the stay in a hotel, for instance due to heating or hot water preparation. For Switzerland, the average $\mathrm{CO}_{2}$ emission per visitor night in a hotel is estimated at $11 \mathrm{~kg} \mathrm{CO}_{2}$ (Schegg and Amstutz, 2004). For New Zealand, the corresponding estimate is $8 \mathrm{~kg} \mathrm{CO}_{2}$ per visitor night (Becken and Patterson, 2006), whereas the German Environmental Protection Agency uses a value of $18 \mathrm{~kg} \mathrm{CO}_{2}$ (Schächtele and Hertle, 2007). Here, I use an average of these values, $12 \mathrm{~kg} \mathrm{CO}$ per visitor night. A 
Table 3. Annual $\mathrm{CO}_{2}$ emissions from hotel usage by NILU personnel in 2005, 2006 and 2007, expressed as annual totals $\left(\mathrm{tCO}_{2}\right)$ as well as annual totals per employee $\left(\mathrm{tCO}_{2}\right)$ and per employed scientist $\left(\mathrm{tCO}_{2}\right)$.

\begin{tabular}{rrrr}
\hline Year & $\mathrm{CO}_{2}$ & $\mathrm{CO}_{2}$ /employee & $\mathrm{CO}_{2}$ /scientist \\
\hline 2005 & 16 & 0.12 & 0.27 \\
2006 & 16 & 0.10 & 0.21 \\
2007 & 23 & 0.14 & 0.29 \\
\hline
\end{tabular}

detailed analysis of the travel information for the year 2007 revealed that a NILU employee spent on average 3.4 nights away from home per trip. This number was also used for the other years to calculate the corresponding $\mathrm{CO}_{2}$ emission from the number of trips undertaken.

\section{Results}

Table 2 summarizes the distances traveled and corresponding $\mathrm{CO}_{2}$ emissions caused by NILU's staff. In total, NILU employees traveled between 2.2 and 3 million $\mathrm{km}$ per year. This corresponds to $15000-19000 \mathrm{~km}$ per employee. Since most trips, especially the longer ones, were undertaken by scientists, it makes sense to count the emissions per scientist and use this as the main yardstick for later comparisons. The average NILU scientist traveled $30000-43000 \mathrm{~km}$, roughly once around the Earth, every year. The resulting $\mathrm{CO}_{2}$ emissions ranged from 269-368 t/year, which corresponds to 1.8$2.3 \mathrm{tCO}_{2}$ per employee or 3.7-5.2 $\mathrm{tCO}_{2}$ per scientist. More than $97 \%$ of these emissions were caused by air transportation, less than $3 \%$ by ground transportation. Hotel usage (Table 3) adds another 5\% and, thus, is a relatively minor contributor to the $\mathrm{CO}_{2}$ emissions.

The total travel-related $\mathrm{CO}_{2}$ emissions (i.e., sum of transportation emissions and emissions from hotel usage) for 2005-2007 are listed in Table 4 and the per-capita emissions for the year 2007 are compared with total national per-capita emissions in various countries in Table 5. The per-capita emissions (2.4 and 5.0 $\mathrm{tCO}_{2}$ per employee and per scientist, respectively) appear relatively small compared to the Norwegian average per-capita emission $\left(19.1 \mathrm{tCO}_{2}\right)$. However, Norway's per-capita $\mathrm{CO}_{2}$ emissions are among the highest in the world, which is due mainly to oil production which accounts for almost $60 \%$ of the national emissions. Such a comparison is, thus, misleading. NILU's travel-related per-scientists emissions are much higher than the Norwegian emissions from road transport. NILU's per-scientist emission are higher than the total per-capita emissions in many Asian countries, including China, and they also exceed the global average per-capita $\mathrm{CO}_{2}$ emissions. They are furthermore comparable to the total per-capita emissions in some highly industrialized nations, for instance in France, Swe-
Table 4. Total annual travel-related $\mathrm{CO}_{2}$ emissions by NILU personnel in 2005, 2006 and 2007, expressed as annual totals $\left(\mathrm{tCO}_{2}\right)$ as well as annual totals per employee $\left(\mathrm{tCO}_{2}\right)$ and per employed scientist $\left(\mathrm{tCO}_{2}\right)$.

\begin{tabular}{rrrr}
\hline Year & $\mathrm{CO}_{2}$ & $\mathrm{CO}_{2}$ /employee & $\mathrm{CO}_{2} /$ scientist \\
\hline 2005 & 327 & 2.4 & 5.5 \\
2006 & 285 & 1.9 & 3.9 \\
2007 & 391 & 2.4 & 5.0 \\
\hline
\end{tabular}

den or Switzerland. Given that these emissions occur in just 24 days of the year (the average time a NILU scientist spent abroad), this result is quite remarkable.

In this study I have made emission estimates only for $\mathrm{CO}_{2}$ and more than $90 \%$ of these emissions resulted from aircraft use. However, aircraft impact climate not only through their $\mathrm{CO}_{2}$ emissions. They emit nitrogen oxides which produce ozone, a particularly effective greenhouse gas at cruising altitudes (Fabian and Kärcher, 1997). Aircraft also emit water vapor, which at these high altitudes also adds a small positive radiative forcing. Furthermore, aircraft produce contrails and possibly also lead to enhanced cirrus cloud cover, both causing a positive radiative forcing (Marquart et al., 2003). The radiative forcing due to these effects is more uncertain than the radiative forcing from $\mathrm{CO}_{2}$ but in total may effectively more than double the $\mathrm{CO}_{2}$ radiative forcing (Penner et al., 1999). Consequently, the per-capita climate impact of NILU's business trips is relatively larger than the per-capita $\mathrm{CO}_{2}$ emissions alone would suggest. In other words, if radiative forcing values instead of $\mathrm{CO}_{2}$ emissions would have been compared, the relative importance of NILU's travel would increase.

An important question remaining from this study is how representative the travel behavior of NILU's scientists is for the whole (atmospheric) science community. There are several factors which may produce larger travel activity of a NILU scientist compared to other scientists. Most importantly, Norway is on the northern end of Europe such that almost all trips by NILU scientists involve relatively long distances. Furthermore, a substantial fraction of NILU's revenue comes from projects sponsored by the European Union, the United Nations and other international sources. NILU also maintains small branch offices in various countries (e.g., United Arab Emirates, Poland) and operates monitoring stations both in the Arctic and in Antarctica which need to be visited regularly. Finally, NILU employees also travel occasionally between the Kjeller and Tromsø offices. However, there are also factors that discourage NILU scientists from traveling, for instance the fact that few intercontinental flights are departing from Oslo, such that nearly always multiple flights are needed to reach a destination on another continent. This is even worse for scientists working in Troms $\varnothing$ who must travel to Oslo first, before embarking 
Table 5. Comparison of the NILU travel-related $\mathrm{CO}_{2}$ emissions for 2007 with annual per-capita total $\mathrm{CO}_{2}$ emissions for various countries.

\begin{tabular}{lrrr}
\hline Emission source & Year & $\mathrm{CO}_{2}(\mathrm{t})$ & Reference \\
\hline NILU employee, travel & 2007 & 2.4 & this study \\
NILU scientist, travel & 2007 & 5.0 & this study \\
Norway & 2004 & 19.1 & Marland et al. (2007) \\
Norway, oil production & 2000 & 11.4 & EDGAR 32FT2000 (Olivier et al., 2001) \\
Norway, road transport & 2000 & 1.9 & EDGAR 32FT2000 (Olivier et al., 2001) \\
United States & 2004 & 20.4 & Marland et al. (2007) \\
United Kingdom & 2004 & 9.8 & Marland et al. (2007) \\
Germany & 2004 & 9.8 & Marland et al. (2007) \\
France & 2004 & 6.2 & Marland et al. (2007) \\
Sweden & 2004 & 5.9 & Marland et al. (2007) \\
Switzerland & 2004 & 5.5 & Marland et al. (2007) \\
Global average & 2004 & 4.5 & Marland et al. (2007) \\
China & 2004 & 3.8 & Marland et al. (2007) \\
India & 2004 & 1.2 & Marland et al. (2007) \\
\hline
\end{tabular}

on an international flight. The long duration of such trips is a strong incentive for reducing the number of trips. In a comment to this paper, Tolonen-Kivimäki et al. (2008) report that the travel-related $\mathrm{CO}_{2}$ emissions of scientists from the Finnish Meteorological Institute (FMI) calculated with a similar methodology as adopted in this paper were about $40 \%$ lower than those of NILU scientists. However, FMI's main task is to provide operational weather forecasts, not research, and it is likely that personnel working on such operational tasks travel less than research scientists. It is, thus, quite likely that the $\mathrm{CO}_{2}$ emissions of FMI's research scientists are as high as those of NILU's scientists.

A larger number of studies such as this one and the report by Tolonen-Kivimäki et al. (2008) will be needed to fully evaluate the climate impact of scientists. Atmospheric researchers, most of whom are concerned about the climate impact of anthropogenic activities, may actually travel less than other scientists, making a more complete assessment all the more important. Still, it is clear from this study that travel-related $\mathrm{CO}_{2}$ emissions by researchers are substantial and need to be taken into account. Awaiting a more complete assessment and assuming in the meantime that the percapita emissions of the NILU scientists are typical at least for researchers in Norway, the total $\mathrm{CO}_{2}$ emissions caused by the travel of all Norwegian research scientists can be calculated. According to RCN (2008), 54000 persons were involved in research and development activities in Norway in the year 2005. As this number includes part-time personnel, the number of person years spent in research and development, 30500 , may be a more appropriate scaling factor. Assuming that Norwegian researchers emit $5 \mathrm{tCO}_{2}$ per person year on travel, the total number for Norway would be $152.5 \mathrm{ktCO}_{2}$, which is almost $0.2 \%$ of Norway's $\mathrm{CO}_{2}$ emissions.

\section{Conclusions}

In this paper, the $\mathrm{CO}_{2}$ emissions of the employees working at an atmospheric research institute (NILU) caused by all types of business travel (conference visits, workshops, field campaigns, instrument maintainance, etc.) were calculated for the years 2005-2007. More than 90\% of the emissions were caused by air travel, $3 \%$ by ground travel and about $5 \%$ by hotel usage. The travel-related annual emissions were between 1.9 and $2.4 \mathrm{tCO}_{2}$ per employee or between 3.9 and $5.5 \mathrm{t} \mathrm{CO}_{2}$ per scientist. For comparison, the total annual per capita $\mathrm{CO}_{2}$ emissions are $4.5 \mathrm{t}$ worldwide, $1.2 \mathrm{t}$ for India, $3.8 \mathrm{t}$ for China, $5.9 \mathrm{t}$ for Sweden and $19.1 \mathrm{t}$ for Norway. Norway's per capita $\mathrm{CO}_{2}$ emissions are among the highest in the world, due to large emissions from the oil industry, and are probably not suitable for comparison. However, compared to the total per capita emissions of other nations, NILU's $\mathrm{CO}_{2}$ emissions from business travel are quite high, given that the emissions occur during only 24 days of the year. On a perscientist basis, they even exceed the global average per capita emission. Assuming that the per capita emissions derived in this study are typical at least for Norwegian researchers, travel by the Norwegian research and development personnel would account for almost $0.2 \%$ of the national total $\mathrm{CO}_{2}$ emissions. The importance of the travel-related emissions increases further when considering that most of these emissions are due to air travel, whose total radiative forcing effect (including high-altitude ozone formation, water vapor emissions and contrail formation) may be more than twice the radiative forcing due to the $\mathrm{CO}_{2}$ emissions alone.

Given the substantial climate impact of transportation, scientists should re-think their current travel behaviour. Also funding agencies should re-evaluate their funding criteria. Currently, international collaboration is highly encouraged both by national as well as international funding bodies. 
Consequently, research proposals involving a lot of travel tend to be more successful than proposals with less travel, even though the scientific benefit from the enhanced travel may not always be clear. While continued support for international collaboration is desirable, avoiding unnecessary travel should also be encouraged in order to reduce the climate impact of scientific research.

Acknowledgements. I appreciate the support of NILU's directors, G. Jordfald and P. Berg and the department director K. Tørseth, for this research, and for their approval to publish these data. I thank NILU's administrative personnel, particularly E. Braathen, for their help in compiling travel statistics.

Edited by: M. Heimann

\section{References}

Babikian, R., Luchachko, S. P., and Waitz, I. A.: The historical fuel efficiency characteristics of regional aircraft from technological, operational and cost perspectives, J. Air Transp. Manag., 8, 389400, 2002.

Becken, S. and Patterson, M.: Measuring National Carbon Dioxide Emissions from Tourism as a Key Step Towards Achieving Sustainable Tourism, J. Sustainable Tourism, 14, 323-338, doi:10.2167/jost547.0, 2006.

Fabian, P. and Kärcher, B.: The impact of aviation upon the atmosphere, Phys. Chem. Earth, 22, 503-598, 1997.

IPCC (Intergovernmental Panel on Climate Change): Climate Change 2007: The Physical Science Basis, in: Contribution of Working Group I to the Fourth Assessment Report of the Intergovernmental Panel on Climate Change, edited by: Solomon, S., Qin, D., Manning, M., Chen, Z., Marquis, M., Averyt, K. B., Tignor, M., and Miller H. L., ISBN 978-0521-88009-1, Cambridge University Press, Cambridge, United Kingdom and New York, NY, USA, 996 pp., 2007.

Kim, B. Y., Fleming, G. G., Lee, J. J., Waitz, I. A., Clarke, J.-P., et al.: System for assessing Aviation's Global Emissions (SAGE), Part 1: Model description and inventory results, Transportation Res. D-Tr. E., 12, 325-346, 2007.

Krause, S., Buytaert, W., and Krueger, T.: The carbon footprint of academic travelling - assessing the sustainability of different ways of travelling to the EGU Assembly, Geophys. Res. Abstr., 9, 11212, 2007.
Lee, J. J., Lukachko, S. P., Waitz, I. A., and Schäfer, A.: Historical and future trends in aircraft performance, cost, and emissions, Annu. Rev. Energ Env., 26, 167-200, 2001.

Marland, G., Boden, T. A., and Andres, R. J.: Global, Regional, and National Fossil Fuel $\mathrm{CO}_{2}$ Emissions, Trends: A Compendium of Data on Global Change, Carbon Dioxide Information Analysis Center, Oak Ridge National Laboratory, US Department of Energy, Oak Ridge, Tenn., USA, 2007.

Marquart, S., Ponater, M., Mager, F., and Sausen, R.: Future development of contrail cover, optical depth, and radiative forcing: Impacts of increasing air traffic and climate change, J. Climate, 16, 2890-2904, 2003.

Morrell, P.: An evaluation of possible EU air transport emissions trading scheme allocation methods, Energ. Policy, 35, 55625570, 2007.

Olivier, J. G. J. and Berdowski, J. J. M.: Global emissions sources and sinks, in: "The Climate System", edited by: Berdowski, J., Guicherit, R., and Heij, B. J., 33-78, A. A. Balkema Publishers/Swets \& Zeitlinger Publishers, Lisse, The Netherlands, ISBN 90-5809-255-0, 2001.

Penner, J. E., Lister, D. H., Griggs D. J., Dokken, D. J., and McFarland, M.: Aviation and the Global Atmosphere, Cambridge University Press, UK, 373 pp., 1999.

RCN (The Research Council of Norway): Report on Science \& Technology Indicators for Norway 2007, ISBN 978-82-1202506-6, The Research Council of Norway, 80 pp., 2008.

Schächtele, K. and Hertle, H.: Die $\mathrm{CO}_{2}$ Bilanz des Bürgers - Recherche für ein internetbasiertes Tool zur Erstellung persönlicher $\mathrm{CO}_{2}$ Bilanzen, Endbericht im Auftrag des Umweltbundesamtes, Förderkennzeichen 20642 110, available at: http:// www.umweltdaten.de/publikationen/fpdf-1/3327.pdf, Institut für Energie- und Umweltforschung Heidelberg GmbH, Heidelberg, 2007.

Schegg, R. and Amstutz, M.: Energiekennzahlen für die Schweizer Hotellerie - ein Forschungsprojekt des Bundesamtes für Energie, available at: www.hotelpower.ch/ver_francaise/pdf/hotelpower_ energiekennzahlen.pdf, 2004.

Tolonen-Kivimäki, O., Tuomenvirta, H., and Laaksonen, A.: Interactive comment on "The travel-related carbon dioxide emissions of atmospheric researchers" by A. Stohl, Atmos. Chem. Phys. Discuss., 8, S2757-S2758, 2008. 